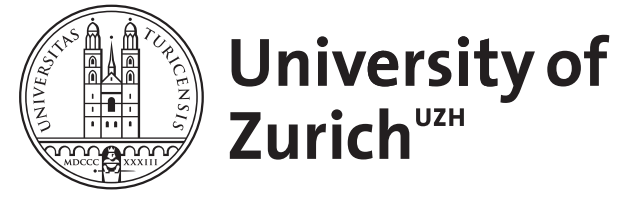

Zurich Open Repository and Archive

University of Zurich

University Library

Strickhofstrasse 39

CH-8057 Zurich

www.zora.uzh.ch

Year: 2016

\title{
The future of legal history: Roman law
}

Babusiaux, Ulrike

DOI: https://doi.org/10.1093/ajlh/njv008

Posted at the Zurich Open Repository and Archive, University of Zurich ZORA URL: https://doi.org/10.5167/uzh-143367

Journal Article

Originally published at:

Babusiaux, Ulrike (2016). The future of legal history: Roman law. American Journal of Legal History:611.

DOI: https://doi.org/10.1093/ajlh/njv008 


\section{HEINONLINE}

Citation:

Ulrike Babusiaux, The Future of Legal History: Roman

Law, 56 Am. J. Legal Hist. 6, 11 (2016)

Content downloaded/printed from $\underline{\text { HeinOnline }}$

Sun Oct $120: 03: 302017$

-- Your use of this HeinOnline PDF indicates your acceptance of HeinOnline's Terms and Conditions of the license agreement available at http://heinonline.org/HOL/License

-- The search text of this PDF is generated from uncorrected OCR text.

-- To obtain permission to use this article beyond the scope of your HeinOnline license, please use:

\section{Copyright Information}

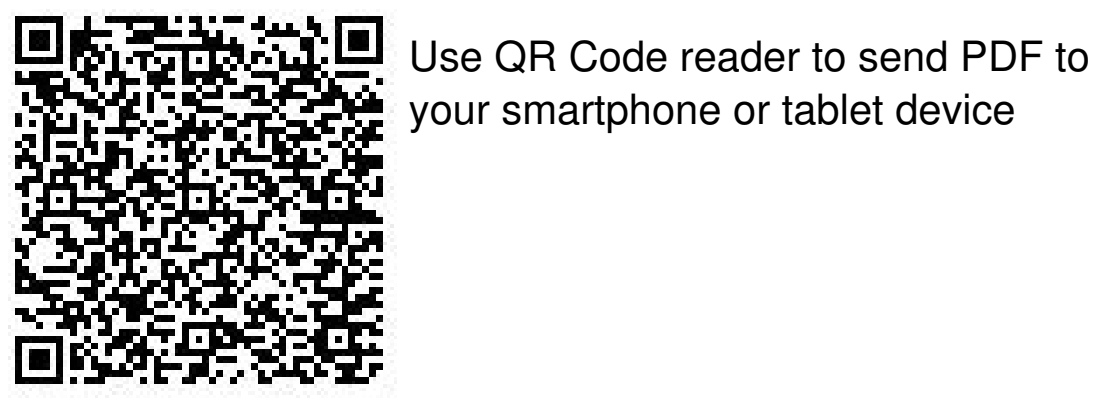




\title{
The Future of Legal History: Roman Law
}

\author{
Ulrike Babusiaux*
}

Being faced with the task of writing an essay on the future of one's own subject is both a tremendous opportunity and an outrageous risk: an opportunity, because one has to render an account of the current state of research as well as its capacities for future development. One might even be able to caution the community about possible aberrations or meanders. However, this creative power has to be weighed against the risk that one's obviously subjective assessments might be rejected. This danger is particularly great if one strives to present a finely nuanced and sophisticated view, as one always runs the risk of getting caught between two stools. Nevertheless, scientific progress hinges on dissent and on a passionate, insatiable thirst for knowledge. The following brief considerations should hence serve as a thought-provoking impulse as well as a subjective snapshot of the inner workings of the discipline of 'Roman law', which generally considers itself as a sub-discipline of legal history, at least in the context of university structures. Any suggestions that might help stop gaps, mend errors, or even provide alternatives to the observations given here, are therefore warmly welcome.

\section{LOOKING BACK}

Asking about the future inevitably raises the question about the past and its influence on the current state of the discipline. To begin with, a couple of observations on the tradition of Roman law in Europe and in the Anglo-American world are therefore in order.

In Europe, the study of Roman law has a longstanding tradition as an analysis of the legal foundations of one's own codification of private law. On the one hand, this tradition led to the fact that Roman law never migrated into the philosophy faculties but rather remained a genuine subject of legal education. On the other hand, the connection between Roman law and modern private law resulted in the development of specific research methods and approaches. As a consequence, European law faculties, especially in the German-speaking countries, focused mainly on the private law developed by Roman jurists. Within the Pandectist tradition, questions of dogma

* Professor of Roman Law, Private Law, and Comparative Law at the University of Zürich. Special thanks to my assistant Natalie Balasz and to Henry Heitmann-Gordon (Ludwig-Maximilians-Universität München, Graduate School Distant Worlds) for their help with the English version. All remaining errors are my own.

(c) The Author 2016. Published by Oxford University Press. All rights reserved.

For Permissions, please email: journals.permissions@oup.com 
long heavily outweighed interests underpinned by socio-historical or even anthropological or philosophical interests. However, already at the beginning of the $20^{\text {th }}$ century, Leopold Wenger began developing an alternative to the strictly private lawfocused dogmatic study of Roman law. ${ }^{1}$ This new model of ancient legal history now aimed to take into account not only the constitutional and philosophical foundations of Roman law, but also the cultural influences and interactions that had helped shape it. Despite the impressive and fundamental achievements made by applying this broadened point of view, it never quite managed to break into the scientific mainstream. Nevertheless, Wenger's groundbreaking departure is responsible for much of the research we take for granted today, including the study of the working conditions of Roman jurists, many accomplishments in legal papyrology, and our insights into the interaction between Roman law and the provincial preconditions. Combining all these approaches and embracing non-legal disciplines-such as philosophy, medicine, or rhetoric-further promises new and deeper insights into the Roman jurists' legal interpretation. ${ }^{2}$

As for the English-speaking areas, especially the United States, the state of research into Roman law was completely different because of the differences in legal system. On the one hand, research on Roman law has always been a peripheral phenomenon within common law systems. On the other hand, those few jurists who concerned themselves with the subject were much more willing to delimit their discipline in a much more generous fashion by integrating questions from cultural sciences into their research - we need only think of Arthur Schiller's still innovative work, which devoted a great deal of space to provincial legal practice in a textbook already in the 1970 s. $^{3}$ More recent American research also promises to provide interesting impulses to the more traditional European approaches, because it dares to work with concepts and theories gleaned from cultural sciences and sociology. ${ }^{4}$ However, these innovative approaches sometimes lack awareness of the fact that their research questions have already been the subject of research on the European continent, with some having been discussed for centuries. This research, usually written in languages other than English, is often (though not always!) acknowledged only on the sidelines or even completely ignored within the English scientific discourse. Unfortunately, this causes many valuable achievements of continental European studies of Roman law to fall into oblivion, or allows knowledge to be 'newly discovered' when it has merely been

1 Leopold Wenger, Der heutige Stand der römischen Rechtswissenschaft. Erreichtes und Erstrebtes (Inaugural lecture Vienna 1926, Munich, Beck 1927). Wenger was inspired by the research of Ludwig Mitteisespecially his work, Römisches Privatrecht bis auf die Zeit Diokletians, vol 1: Grundbegriffe und Lehre von den Juristischen Personen (Leipzig, Duncker \& Humblot 1908)-who paradoxically rejected Wenger's programme.

2 Exemplary is Dieter Nörr's book. It is easily accessible in his collected writings, Tiziana J Chiusi, HansDieter Spengler, and Wolfgang Kaiser (eds), Dieter Nörr, Historiae Iuris Antiqui I-III (Goldbach 2003) as well as in Tiziana J Chiusi, Hans-Dieter Spengler, and Javier Paricio (eds), Dieter Nörr, Schriften 2001-2010 (Madrid, Marcial Pons 2012).

3 An American Experience in Roman Law: Writings from Publications in the United States (Vandenhoeck \& Ruprecht, Göttingen 1971). Another innovative textbook worth mentioning is his Roman Law: Mechanisms of Development (Mouton, The Hague/New York 1978).

4 For a representative example, see Clifford Ando, Imperial Ideology and Provincial Loyalty in the Roman Empire (University of California Press 2000); idem, Law, Language and Empire in the Roman Tradition (University of Pennsylvania Press 2011). 
overlooked. ${ }^{5}$ It is further obvious that even in Europe scientific discussion is not a game of equal opportunities played by all countries and in all languages, and one could hardly make the serious claim that all the research conducted on Roman law in these very different countries enjoys equal weight: the languages spoken in the Netherlands, Poland, or Slovakia, for instance, are simply not linguae francae, and a researcher seeking to be heard in the field of Roman law would have to publish his results in Italian, German, French, or English. For quite some time, there has even been a noticeable decline in exchange between the German-speaking, Italian-speaking, and French-speaking research communities working on Roman law simply because language skills are lacking - a development that is lamentable due to the strong $19^{\text {th }}$ century tradition of this productive exchange. Also within the European community of researchers studying Roman law, English has hence grown in significance, which brings us to the present day.

\section{THREE TRENDS}

For contemporaries, describing or even analysing their current state is almost impossible because they are inextricably enmeshed in it. Considering the trajectories sketched out above, it nevertheless serves to illuminate three aspects that stand out most clearly.

\section{First trend: internationalization}

Research on Roman law has become increasingly internationalised in the last 20 years. In Europe the community of researchers first noticeably expanded after the fall of the iron curtain, when former communist countries of Eastern Europe regained complete access to the European and international scientific discourse. This allowed new relations to be established to substantial traditions and schools of thought that had persisted in certain countries, such as Poland and Hungary, without having been lost in the communist era. Other Eastern European countries not only saw the drafting of new civil codes, but also experienced a concomitant introduction or resuscitation of the tradition of Roman law. This internationalization of research is further supplemented by China's recently ignited interest in Roman law, which similarly grew out of the reception of core elements of private law for a modern legal system. Various cooperations between European countries and Chinese universities have also engendered increasing interest in Roman law as a historical subject, leading Chinese scholars to partake in the field. Asia, which has had an own approach to Roman law within Japan and Korea for quite some time, has thereby begun to really establish itself as an independent and self-sufficient site of Roman law research alongside North and South America, and Europe.

\section{Second trend: syntheses}

In the last five years, both the Anglo-American and the German communities attempted to produce syntheses of Roman (private) law. The Anglo-American project: The Oxford Handbook of Roman law and Society, edited by Clifford Ando, Paul 
du Plessis, and Kaius Tuori, pursues, as the title already implies, a contextualisation of the traditionally dogmatic study of Roman law. To use the words from the blurb: the handbook (in print for 2016) 'showcases new approaches and methodologies for the study of Roman law', 'demonstrates the contributions that these new approaches and methodologies could make to the traditional dogmatic understanding of Roman law', and 'provides additional narrative in which the study of Roman law is integrated into the wider study of the ancient world'. The German-speaking counterpart is the Handbuch des römischen Privatrechts, ${ }^{6}$ co-edited by the author herself. Conceived by the editors to provide a 'modern' view of Roman private law, this aim was pursued by bringing together substantive and procedural law perspectives and extensively incorporating traditions that went beyond Justinian's codifications. It further aims to provide the reader with a good understanding of the chronological development of private law from archaic legal traditions to the era of Justinian. ${ }^{7}$ In doing so, the book also attempts to dissolve the apparent opposition between dogmatic research and approaches in ancient studies in productive unity. Despite the similarities apparent in the aims of these projects, they show crucial differences in their methodology, context, and scope: the project in German wants to focus on private law and thoroughly inform about the current state of research from a legal perspective, whereas the English project programmatically encompasses all the other legal fields and is mainly drafted from a non-legal point of view. The syntheses these projects will produce can therefore be expected to be complementary rather than competitive.

\section{Third trend: plurality of research approaches}

As the two contrasting synthetic projects showed, the approaches to Roman law have immensely differentiated as well as broadened within the last 20 years not only in regards to the sources but also to their methodology. Besides the on-going traditional engagement with the dogmatic fundamentals of private law, the code of Justinian has also attracted approaches with interests in social history, cultural science, literary criticism, and economics. The field of Roman law has further expanded its source basis: the Corpus iuris civilis has been supplemented with epigraphical testimonies, archaeological finds, and literary sources. Legal documents and papyri are increasingly viewed as relevant also for the study of Roman law and are, therefore, often linked to legal writings by Roman jurists or to imperial laws. Furthermore, the source editions made in the 19th century, which continue to be the basis of research, are now being critically re-assessed. ${ }^{8}$ Even the diachronic impact of Roman law is

6 Ulike Babusiaux, Christian Baldus, Wolfgang Ernst, Franz-Stefan Meissel, and Johannes Platschek (eds), Handbuch des römischen Privatrechts. Visit the project homepage at: https://idcmslive01.uzh.ch/rwi/live/ lehreforschung/alphabetisch/babusiaux/HRP2.html.

7 The structure is informed by procedural law. The volume is headed by an introduction to the historical fundamentals of Roman private law (A), which includes a description of the types of juridical acts in private law. It is followed by a section regarding the law of persons (B). The following section entitled, 'Res', covers property law and inheritance law (C). The latter only focusses on the law of succession. The last part (D), which comprises about half the entire project, addresses all the different actions.

8 For the textual tradition of Late Antiquity, see especially the ERC project (Advanced Grant) headed by Dario Mantovani: REDHIS—Rediscovering the hidden structure. A New Appreciation of Juristic Text and Patterns of Thought in Late Antiquity at the Università di Pavia, see: http://redhis.unipv.it/. 
now being more fully fathomed: traditional work on the history of dogma is flanked by investigations that examine the continuing effect of Roman law in Byzantium and in Bologna, its influence on Canon Law, and the reception of Roman law in England. Last but not least, Roman law is no longer the sole preserve of the legal profession: ancient historians, philologists, and economists also deal with the ancient material primarily passed on by Justinian in order to gain information for their research from various legal sources. Without exaggeration, one must, therefore, conclude that given the abundance of people and methods involved, Roman law is currently at the centre of an unprecedented plurality of academic interests. Hopefully their analyses of the Roman legal sources and the lives and work of the Roman lawyers will constructively benefit one another and incorporate the results produced across this variety of fields.

\section{WHAT REMAINS?}

In sum, these three trends allow one to get one's bearings about the current state of the subject. First, it is clear that internationalization and the need for syntheses are related: when dealing with new questions and new traditions, finding one's own footing is always a necessary step. The plurality of approaches can similarly be tied back to the field's increasing internationalization. The more people with different cultural backgrounds participate in research on legal history, the more varied the approaches to the sources must be. But what does this mean for the subject itself?

The task of future research on Roman law can only be to combine the traditional dogmatic study of private law with the impulses offered by the ancient history of law and modern trends in ancient studies. These two perspectives are not opposites, but can be mutually productive and lead to new questions when joined, which in turn also lead to new insights. The increase in the scope and ambition of research objectives and methods will further challenge scholars of Roman law to re-negotiate their place in the complex academic world. Furthermore, they will have to be able to handle studies written in all the languages of the world, to make sense of them, and to tie them into their own research. On the one hand, this calls for the willingness to comprehensively assess the state of research beyond narrow disciplinary boundaries. On the other hand, scholars will have to continuously question their own certainties and allow new insights to enter into their research. More than ever before, this will also challenge every scholar to separate relevant issues from the irrelevant and to distinguish actual innovative research from purely reproductive academic epigonism. Furthermore, internationalised, i.e. linguistically and methodologically diversified research with its broad personnel base now needs quality assurance and critical review by the expert community.

Reviews, peer reviews, and discussions at conferences must, therefore, entail real engagement with the ideas of others. Multidisciplinary and international discourse provides us with the freedom to openly address the weaknesses and strengths of contributions (not in an accusatory manner) and to give assessments without false consideration. For the jurists among Roman law researchers, this task may well involve reminding the community that the surviving writings of Justinian are in fact legal literature. As such, these works are not simply quarries that can be mined for information on social realities, on scientific writing in ancient times, or on the educational 
horizons of lawyers. These works are mainly to be considered as technical literature with its own scientific instruments, its own themes, specific tasks, and a largely independent culture of reasoning. Of course this genre is not isolated from the rest of the sciences of the ancient world, nor did Roman jurists move in a vacuum. Nevertheless, the increasing value of contextualization of legal writings in the study of Roman law lies precisely in allowing the specific character of legal texts to emerge more clearly, both in its consequences (and limitations) and especially with regard to all its implications. Pertinent areas for such reflection include, for example, the Roman doctrine of legal sources and the influence of imperial law on the development of law, but also the expression and development of individual private law institutions. In addition, it equally affects the influence of provincial legal views on contract and family law and the importance of religious ideas within the law of inheritance or the importance of lawyers in legal procedures and in the legal sphere.

As Roman law has been taught and studied for centuries, engaging with the ancient sources and their interpretations further provides the opportunity to become more familiar with earlier models and patterns of interpretation. Doing so exposes the splinters in the eyes of previous scholars, giving rise to the question concerning our own blind spots caused by our unconscious preconditions. This reflection allows the scholar to bridge the gap between the historical perspective and modern law: the concern should have less to do with uncovering past misinterpretations or with providing lessons for the present and more to do with sharpening one's own perception and overcoming prejudices regarding both ancient and contemporary law. The purpose of the historical perspective is nothing less than to question apparent certainties and develop new questions to present jurisdiction, legislation, and legal doctrine, as well as to the circumstances under which contemporary jurisprudence operates. Siegfried Kracauer's dictum that 'history is a film' therefore applies also to legal history: every successful investigation of an ancient, medieval, or modern phenomenon of Roman law leaves traces that contribute to shaping the scholar's perception, but also the one of his readers and listeners.

\section{POSTSCRIPTUM}

In delving into a piece entitled, 'The Future of Legal History', some readers may have expected thoughts on the survival of the subject, or even regarding its strategic orientation for the future. One might even have preached to the choir of pervasive cultural pessimism by deliberating on the faded importance of history and students' lack of education in ancient languages. In my opinion, there is no reason to despair. In pursuing the purpose developed here, in examining and critically reflecting the self-imposed goals set by scholars in all areas of Roman law, the subject will remain attractive to scholars and students alike without special effort, and especially without artifice. 